\title{
Profit Sharing among Labour, Mudharib and Shahibul Maal under Mudharabah Contract: Evidence from Indonesia
}

\author{
Atih Rohaeti Dariah \\ Yuhka Sundaya ${ }^{\mathrm{b}}$ \\ Neneng Nurhasanah ${ }^{c}$ \\ Bandung Islamic University
}

\begin{abstract}
This paper aims to study the probability of changes in income distribution as a result of business practice of profit sharing agreement among production factors of workers/labour, managers (mudharib) and investors (shahibul maal) within the framework of mudharabah scheme. The ordered logit econometrics model was applied for this purpose. Data were taken from entrepreneurs/businessmen who applied the mudharabah scheme in Indonesia. The research result shows five variables that determine the probability of changes in distribution. These are business profits, company age, changes in the organisation, total employment and the level of mandate of mudharib.
\end{abstract}

Keywords: Functional income distribution, mudharabah, profit sharing JEL classification: 012

\section{Introduction}

One of the institutional businesses of profit sharing in Indonesia is mudharabah. Based on a study of its meaning, scholars of figh and the Financial Services Authority of Indonesia define mudharabah as joint ventures, financial agreements or investment of funds from the funder (shahibul maal) to the fund manager (mudharib) to conduct certain business activities conforming to Islamic law with profit sharing agreements based on the terms agreed upon (an-Nabhani, 2010; Financial Services Authority of Indonesia, 2017). When viewing at the economics literature, in which mudharabah is equal to profit sharing or sharecropping that induces the issue of functional income distribution, placing the workers/labour as one of the parties in joint ventures becomes an interesting topic in the development of Islamic economics and business practices to ensure fairness. Workers will receive additional revenues from profit-sharing apart from

a Faculty of Economics and Business, Bandung Islamic University, Bandung, West Java, Indonesia 40116. Email: atih@unisba.ac.id or ardariah.68@gmail.com (Corresponding author)

b Faculty of Economics and Business, Bandung Islamic University, Bandung, West Java, Indonesia 40116. Email: yuhka@unisba.ac.id

c Faculty of Syariah, Bandung Islamic University, Bandung, West Java, Indonesia 40116. Email: nenengnurhasanah@unisba.ac.id

We wish to thank the Directorate of Higher Education Ministry of Research and Technology Indonesia for financially supporting this study through the Competitive Research Grant, 2016.

Article Info: Received 23 October 2016; Revised 20 January 2018; Accepted 9 March 2018 
their predetermined wage which is called ijarah as a lease on the utilisation of workers' services. When wage rates alone can alter the distribution of income (Molero-Simarro, 2015), then placing workers/labour as partners in mudharabah cooperation is a great opportunity to improve the distribution of income.

In this context, Dariah, Sundaya and Malik (2015) has develop a new thinking which explains how the price of production factors will change in the economic model of mudharabah. Initiating with the discovery of seven propositions coming out of the "Lagrange equation", then juxtaposed with the principle of mudharabah and ijarah, the explanatory variables of income distribution emerged among shahibul maal, mudharib and labour.

One important question that needs to be tested on this new thinking is the probability of change in distribution. This question will become the focus of our discussion and is expected to be a part of the puzzle box of functional income distribution. This paper is organised into five sections. The second part explains the meaning and principles of mudharabah. In the third section, we show data and analytical tools to estimate the changes probability model in functional income distribution. The fourth section presents the results of the estimation model that describes the changes probability in income distribution, and the last part is the conclusion.

\section{Principles of Mudharabah}

Marginalist economists view that the sources of income distribution problems are pricing factors (Mankiw, 2000; Koutsoyiannis, 1979; Sukirno, 2002). The four factors of production are land, labour, capital and entrepreneurship. Each of them has their pricing, i.e. rent, wages, interest and profit respectively. Hayami (2001) continued the school of marginalist thought by saying that income inequality occurred due to the increase of capitalist's income share, which means a decrease in worker's income share. According to this thought, Todaro and Smith (2012) proposed that one of the field interventions for improving income distribution is to arrange the pricing factor as a change in income distribution.

When we talk about capital in the Islamic context, it is related to asset utilisation for investment. In Islamic business perspectives, investment is related to aqads (contract) of partnership, such as mudharabah, with the risk and profit sharing mechanism (Dariah, Sundaya, \& Tresna, 2013). In the literature of figh muamalah, the discussion of a profit-sharing system is inseparable from the concept of cooperation or syirkah. In syirkah, there are at least two types of agreements being used, namely musyarakah and mudharabah. Etymologically, al-syirkah means a mix of one thing with another that would finally become difficult to be distinguished from. Al-syirkah is one form of trade cooperation with certain principles and requirements, or a trade union in terms of positive law.

Terminologically, there are several definitions of al-syirkah:

a. According to Malikiyah scholars:

"Licences for two people in cooperation to exercise legal acts toward their properties." 
b. According to Syafi'iyah and Hanabilah scholars:

"The rights for two or more people to exercise legal acts toward something they have agreed upon."

c. According to Hanafiyah scholars:

"The agreement made between people who cooperate in capital and profit."

Basically, the definitions by fiqh scholars above only differ at the redaction or literary level and yet have the same essence in referring to a cooperation bond between two or more people in trade. All parties involved in al-syirkah have the right to exercise their legal acts and gain profits according to the agreement (Haroen, 2000). There are specific principles of mudharabah as follows (Nurhasanah, 2015):

a. Principle of profit-sharing among parties who are involved in mudharabah agreement. In a mudharabah agreement, net profit should be shared between the shahibul maal and mudharib based on a fair proportion previously agreed upon and explicitly mentioned in the mudharabah contract. The profit sharing cannot be done before the loss is covered and the shahibul maal's equity is fully returned.

b. Principle of loss sharing among people in the agreement. In mudharabah, the principles of balance and justice lie in the sharing of loss among the parties in agreement. The burden of financial loss will entirely fall on capital owners, unless there is some proof of negligence, errors, or fraud by the mudharib/ managers. Meanwhile, the mudharib/managers bear the loss in terms of time, energy and efforts, gaining nothing from their hard work.

c. Principle of clarity. In mudharabah, the amount of capital that a shahibul maal will contribute, the percentage of profits shared, the requirements desired by each party, and the duration of the agreement should be mentioned clearly and firmly. Clarity is the absolute principle in this agreement; hence, a written contract should be made in a mudharabah agreement.

d. Principle of trust and trustworthiness. Trust, ultimately that of capital owners, is the determining element for a mudharabah agreement. If there is no trust from the shahibul maal, a mudharabah transaction will not take place. Shahibul maal can unilaterally end a mudharabah agreement if she/he no longer trusts the mudharib. This trust should be balanced with the trustworthiness of the managers.

e. Principle of prudence. Prudence is the basic and important principle in a mudharabah contract. If the capital owner does not have this principle, he can get scammed and experience financial loss. Meanwhile, if the managers do not have prudence, it would cause the business to fail. In addition to experiencing financial loss, they will lose their time, energy and efforts that have been dedicated to the business, as well as losing the owner's trust.

\section{Methodology}

This study uses quantitative and qualitative primary data through a survey of Muslim/ Moslem businessmen who apply the principle of mudharabah. The entrepreneurs/ 
businessmen population is difficult to measure, so we use a probability sampling technique. Questions delved from a correspondent were in the form of quantitative data such as the company's age, number of managers and workers, company's net income, company's share of profit for workers, shahibul maal, mudharib and average educational background of workers and managers. Most of the qualitative data are in the form of businesses type, main input, target and market reach, manager's education, and work experience of workers that can be objectively revealed according to the company's situation. Questions on qualitative variables such as reasons for profit sharing, efforts to keep trustworthiness and circumspection, role of education in expertise, and work experience provide flexibility and make the answers subjective. For the question of shahibul maal's level of trust for mudharib, a choice of answers with value 1 for the firm believer and 2 for the believer was given, while questions for mandate level (weight of work for mudharib) are provided in answers of light $=0$, moderate $=1$, heavy $=3$.

The focus of this study is the probability of change in income distribution among employees, managers (mudharib) and investors (shahibul maal), which is expressed in the share ratio of workers toward mudharib and shahibul maal. This ratio is ranked according to the following category: low (1), moderate (2), and high (3).

Table 1. Qualitative dependent variables: profit sharing ratio

\begin{tabular}{|c|c|c|c|c|c|c|}
\hline \multirow[t]{2}{*}{ Sector } & \multicolumn{3}{|c|}{ Economic actors } & \multirow{2}{*}{$\begin{array}{c}\text { Average } \\
\text { of share } \\
\text { ratio }\end{array}$} & \multirow{2}{*}{$\begin{array}{l}\text { Rank of } \\
\text { average } \\
\text { share } \\
\text { ratio }\end{array}$} & Interval class* \\
\hline & Labour & Mudharib & $\begin{array}{c}\text { Shahibul } \\
\text { maal }\end{array}$ & & & \multirow[t]{6}{*}{$\begin{array}{l}\text { High }=0.27-0.46 \\
\text { Medium }=0.16-0.26 \\
\text { Low }=0.05-0.15\end{array}$} \\
\hline Trade & 0.27 & 0.33 & 0.40 & 0.42 & High & \\
\hline Industry & 0.24 & 0.31 & 0.45 & 0.32 & High & \\
\hline Agriculture & 0.25 & 0.30 & 0.45 & 0.33 & High & \\
\hline Construction & 0.24 & 0.33 & 0.43 & 0.32 & High & \\
\hline Services & 0.18 & 0.35 & 0.47 & 0.24 & Medium & \\
\hline
\end{tabular}

Note: * Considering minimum, average and maximum profit sharing ratio.

Source: Authors' survey results.

A shift in probability of income distribution for mudharabah principle is estimated by ordered logit models. The model's feature is presented in equation (1) below:

$$
\begin{aligned}
& \text { Prob }\left(\text { share }_{i}=1 \mid X_{i}\right)=\frac{1}{1+\exp \left(\alpha x_{i}-\mu_{1}\right)} \\
& \text { Prob }\left(\text { share }_{i}=2 \mid X_{i}\right)=\frac{1}{1+\exp \left(\alpha x_{i}-\mu_{2}\right)}-\frac{1}{1+\exp \left(\alpha x_{i}-\mu_{1}\right)} \\
& \text { Prob }\left(\text { share }_{i}=3 \mid X_{i}\right)=1-\frac{1}{1+\exp \left(\alpha x_{i}-\mu_{2}\right)}
\end{aligned}
$$

The sign and magnitude of estimated parameters with corresponding meanings can be extracted from the statistical odds ratio that displays information about the 
Table 2. Summary statistics

\begin{tabular}{lcrr}
\hline Variable & Minimum & Mean & Maximum \\
\hline Profit (Rp) & 17.0 & 20.3 & 22.0 \\
Company age & 1.0 & 10.8 & 30.0 \\
Workers & 2.0 & 20.7 & 100.0 \\
Managers & 1.0 & 2.0 & 4.0 \\
Mandate [light $=$ 0, medium = 1, heavy = 3] & 1.0 & 2.5 & 3.0 \\
\hline
\end{tabular}

large magnitude of the highest category compared to the rank below in responding to a change in explanatory variable. The highest ranking is a company that provides the highest wages for its workers. The estimation result repeatedly raises the following independent variables (see Table 2).

\section{Results and Discussion}

Results of the model estimation are presented in Table 3. The left column displays variables which explain changes of probability in income distribution. The estimation results display the value of $z$ statistic (column 2 ) and its probability ( $p$-value). There are three variables which are significantly different from zero: company age, number of managers and profits. Meanwhile, the variables of total workers and level of mandate show a lower $z$ value. Despite this, the statistical information is acceptable considering these two variables have their meaning. The symbol $\mathrm{e}^{\mathrm{b}}$ (Workers) in the third column shows the odds ratio, that is probability of changes in income of the worker compared to the mudharib and shahibul maal, in response to changes in each explanatory variable. On the other hand, in the fourth column, the symbol indicates probability of changes in income of mudharib and shahibul maal in response to a change of each explanatory variable.

The overall share of profit in each sector which is sourced from company profits is different. In Figure 1, the share of labour in all sectors is below 30 percent, the lowest is in services with 18 percent, while shahibul maal gets a relatively high 48 percent. This is because they usually get involved in managing their businesses.

Table 3. Results of ordered logit model estimation

\begin{tabular}{lrrrc}
\hline Explanatory variables & $\mathrm{z}$ & $\mathrm{P}>|\mathrm{z}|$ & $\mathrm{e}^{\mathrm{b}}$ (Workers) & $\begin{array}{c}\mathrm{e}^{\mathrm{b}} \text { (Mudharib and } \\
\text { shahibul maal) }\end{array}$ \\
\hline Profit (Rupiah) & -1.72 & 0.086 & 0.1618 & 6.1808 \\
Company age & 1.26 & 0.209 & 1.4511 & 0.6892 \\
Number of managers & 1.93 & 0.054 & 27.1575 & 0.0368 \\
Number of workers & -0.16 & 0.871 & 0.9597 & 1.0420 \\
Mandatory level & -0.13 & 0.898 & 0.8645 & 1.1567 \\
\hline
\end{tabular}

Description: $\operatorname{LR}$ Chi-sq(6) = 8.69; p-value = 0.1222; Log likelihood $=-10.496312 ;$ Pseudo $R^{2}=0.2927$. 


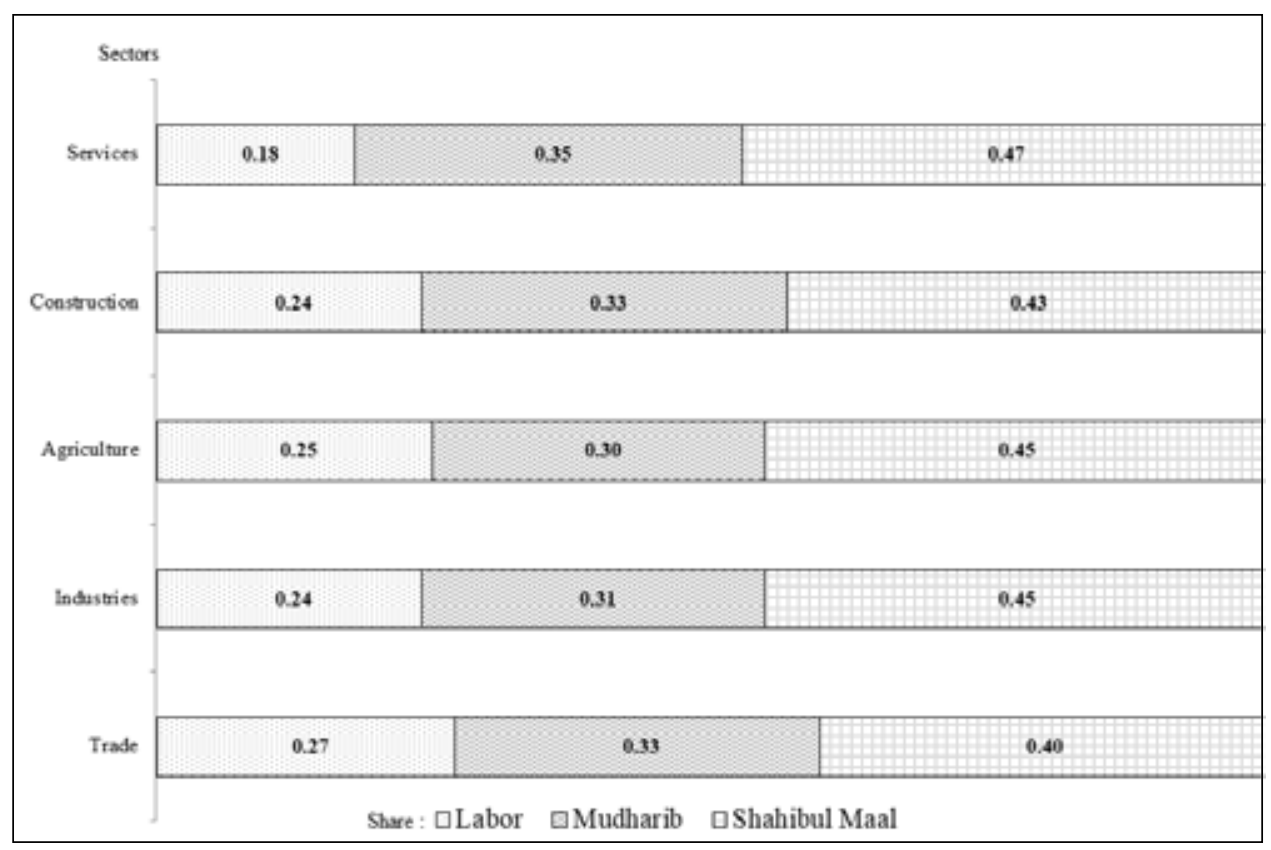

Figure 1. The average profit sharing among labour, mudharib and shahibul maal in five economic sectors

The result of ordered logit models estimation provides information that all the three shared economic actors have opportunities to change. As shown in column 4 of Table 3, additional business profit will reduce the share of labour income distribution. As a result of the additional profit, the figure for workers' income distribution is 0.8645 compared to mudharib and shahibul maal. On the contrary, in column 5, the figure for income distribution of mudharib and shahibul maal is higher at 6.1808 compared to workers. The magnitude of comparison seems large and wide. This is quite logical since the average ratio of profit sharing is basically high (see Table 1), whereby nominally the acquisition of all the actors will increase when profits rise. These findings indicate that the mudharib and shahibul maal view the nominal value of workers as too high when profits rise, thus the ratio of profit sharing tends to be lowered. These findings indicate a conflict or behaviour rivalry among the parties (Bhaduri and Marglin, 1990; Rao, 1987). It seems that the views of Jetin and Kurt (2016) who said that the results of the labour share has no influence on investment can amplify this phenomenon. But when it is associated with one of the authors findings proposition that the income received by workers will not escape the subjective element (moral of mudharib and shahibul maal), then it becomes a phenomenon of interest. Praise be to Allah (SWT) that Islamic business practices will ensure better justice when it was built by the high quality of faith from its actors.

However, the share shift will occur naturally, along with changing phases of production which is indicated by the length of a company's age and additional managers. 
Both are likely to increase the share of labour. The older the company's age, the share probability of workers would increase 1.4511 times higher than the share of mudharib and shahibul maal. This increasing age which is followed by the development of the company organisations indicates business sustainability towards optimal economics of scale, in which case the share of labour will also increase. One additional manager provides shift opportunities in labour income distribution which is 27.1575 higher than mudharib and shahibul maal.

A sustainable business under the mudharabah scheme can be realised due to the strong belief of the shahibul maal to mudharib. Based on our survey results, there are eight elements that determine the level of trust of shahibul maal to mudharib including commitment, control, proximity, company performance, involvement of shahibul maal in business management, easy requirements, market opportunities, attitude and skill, and achievement. To avoid any opportunistic behaviour, the shahibul maal can make seven attempts. Firstly, shahibul maal can still maintain control of the business carried on by mudharib, especially in terms of financial and accounts payable. Secondly, to make sure that mudharib would be transparent (honest and open to development efforts being executed) and also continue to provide socialisation of company values. Thirdly, to ensure the company's management system improvement, particularly for and related to financial and technological systems. Fourthly, to ensure the increasing performance of mudharib for the company. Fifthly, to make sure that mudharib has creative, innovative, credible and accountable skills. Sixthly, to ensure that communication with mudharib is regularly well-managed. Seventhly, to make sure the business is carried out, then leave the rest to Allah (SWT).

In view of mudharib, the trust from shahibul maal is a mandate that needs to be accounted for. This is shown from the survey that in the opinion of mudharib, managing Islamic business is a heavy mandate since it involves responsibility in the world and the hereafter. The mudharib not only sees the mandate as a trust given by shahibul maal, but also a mandate from Allah (SWT). However, there are mudharibs who consider their responsibilities as something easy to do. It means that the mudharib assumes his/her work and duty progress smoothly in a good management system so that their mandate is considered light/easy.

In addition to mudharib's view that the trust from shahibul maal is a mandate, he/she also believes that the mandate and the trust should be well-managed and maintained. The mudharib's efforts to maintain the trust from shahibul maal and manage the mandate should include the following acts. First, mudharib should create a clear business plan while maintaining communication with shahibul maal, being honest and open about any developments in the company, as well as maintaining their professionalism in exercising functions and roles. Second, enhance the company's sustainable performance improvement. Third, keeping the commitments. Fourth, ensure the product quality is maintained and improved. Fifth, continue to monitor and improve the company management systems.

With such a responsibility, it is reasonable that the estimation results show the level of trust mandate carried out by mudharib will assume to reduce the workers profit share. The weight of mudharib's work is potentially shifting the distribution of labour income to 0.1618 compared to mudharib and shahibul maal. Or vice versa, it would 
provide the shift in income distribution of mudharib and shahibul maal to 1.1567 higher than for labour. However, this comparison is not so wide. The weight of work means more responsibilities are attached to mudharib's authority. The enlarged responsibility is compensated by the additional profit sharing for mudharib.

The estimation results in the case of extra workers can reduce the labour profit sharing. The increase in number of workers provide shift opportunities for mudharib and shahibul maal's income distribution which is 1.0420 higher than labour. However, this comparison figure is not that wide. Theoretical propositions also provide such information. Additional labour, without any changes in output prices, will reduce the value of marginal physical product of labour and depress profit sharing for the workers.

Based on the description related to the implementation of Islamic business in Indonesia, it is established that entrepreneurs surveyed have already tried to implement appropriate equitable businesses in accordance with mudharabah practices. Justice is seen from the high average ratio of profit sharing among the three business actors. Efforts made by mudharib in applying the Islamic way of doing business in Indonesia has met the prerequisites of mudharabah contract, that is the fulfillment of moral and managerial prerequisite. Moral prerequisites may include mutual trust, trustworthiness, honesty and staying away from abuses. Managerial prerequisites are related to efforts of improving the management company systems, whether in the reporting or administrative systems.

However, this research finds that the amount of benefit apportioned to workers in various types of businesses is the lowest and tend to decrease when the profit increases. This indicates a high assessment from shahibul maal for their capital value. It is very relevant to the research findings proposition that a too high assessment from shahibul maal for the value of their capital will lower the labour income. Views from most employers surveyed explained that contribution to the company is becoming a basic consideration in determining profit sharing seems to be the main determinant in the shifting of functional income distribution among owners. Additional profits will increase managers' revenue and award investors with higher amount compared to the income of workers, as long as both sides share the same view that contribution to the company is addressed as the asset or cash and the moral standing of both parties have not reach a higher point yet.

Apart from the entire findings above there is a need to proceed with future studies in order to obtain information and provide recommendations for the presence of regulations related to the implementation of Islamic business in the real sector, starting from the permitting process, the principles of Islamic business practices, and a sketch of a more proportional sharing profit.

\section{Conclusion}

Two conclusions can be drawn from the study of functional income distribution under the mudharabah contract. Firstly, in micro-economic activities using mudharabah institutions, there is a potential shift of income distribution through changes in profit sharing. Secondly, the probability of changes in profit sharing depends on the change of business profits, economies of scale, amount of labour, organisational change, and 
level of mandate responsibility of mudharib's authority. Lastly, the potential changes of functional income distribution in mudharabah institutions can become a shift factor for national income distribution in Indonesia, given the appeal of entrepreneurs which is increasing every year.

Understanding a series of studies, research and interpretation of the functional income distribution explanation does not guarantee total uniformity. There will always be specifications of production behaviour attached with different economic institutional practices. These specifications will show models, propositions, methods and conclusions in variation.

\section{References}

An-Nabhani, Taqiyuddin. (2010). Nizham al-iqtishadiy fi al-Islam. Beirut: Dar al-Ummah.

Bhaduri, A., \& Marglin, S. (1990). Unemployment and the real wage: The economic basis for contesting political ideologies. Cambridge Journal of Economics, 14(4), 375-393. https://doi. org/10.1093/oxfordjournals.cje.a035141

Dariah, Atih Rohaeti, Yuhka Sundaya, \& Yuana Ryan Tresna. (2013). Factors pricing concept: Conventional versus Islamic economics (Proceedings of Islamic Economics and Business), Bandung, Indonesia: Economics Faculty, Bandung Islamic University.

Dariah, A.R., Sundaya, Y., \& Malik, Z.A., (2015). Optimizing input and output under the scheme of mudharabah. International Journal of Science and Research (IJSR), 4(5), 227-231.

Financial Services Authority of Indonesia. (2017). Sharia Banking Statistics. Retrieved from http:// www.ojk.go.id/id/kanal/syariah/data-dan-statistik/statistik-perbankan-syariah/Documents/ Pages/Statistik-Perbankan-Syariah---Oktober-2017/SPS\%200ktober\%202017.pdf

Haroen, Nasroen. (2000). Figh mu'amalah (1st ed.). Jakarta: Penerbit Gaya Media Pratama.

Hayami, Yujiro. (2001). Development Economics: From the poverty to the wealth of nations (2nd ed.). Oxford, UK: Oxford University Press.

Jetin, B., \& Kurt, O.E. (2016). Functional income distribution and growth in Thailand: A post Keynesian econometric analysis. Journal of Post Keynesian Economics, 39(3), 334-360. https://doi.org/10.1080/01603477.2016.1202774

Koutsoyiannis, A. (1979). Modern microeconomics (2nd ed.). London, UK: Palgrave Macmillan.

Mankiw, N.G. (2000). Macroeconoomics (4th ed.). New York, NY: Worth Publishers.

Molero-Simarro, R. (2015). Functional distribution of income, aggregate demand, and economic growth in the Chinese economy, 1978-2007. International Review of Applied Economics, 29(4), 435-454. https://doi.org/10.1080/02692171.2015.1016404

Nurhasanah, Neneng. (2015). Mudharabah dalam teori dan praktik. Bandung, Indonesia: PT Refika Aditama.

Rao, J.M. (1987). Productivity and distribution under cropsharing tenancy. World Development, 15(September), 1163-1178.

Sukirno, Sadono. (2002). Pengantar Teori Mikroekonomi (3rd ed.). Jakarta, Indonesia: PT Raja Grafindo Persada.

Todaro, M.P., \& Smith, S.C. (2012). Economic Development (11th ed.). Boston, MA: AddisonWesley. 
